\title{
ЮВІЛЕї
}

\section{ДОКТОРУ МЕДИЧНИХ НАУК, ПРОФЕСОРУ, ЗАВІДУВАЧУ КАФЕДРИ ФАКУЛЬТЕТСЬКОЇ ТЕРАПІЇ ТАРАСУ МИХАЙЛОВИЧУ ГАНИЧУ - 60!}

Здається, ще не затихло відлуння торжества вручення диплома $з$ відзнакою про закінчення медичного факультету Ужгородського університету, хвилювання та радість перших кроків та успіхів у роботі, створення сім'і, поява дітей, внуків, захист кандидатської та докторської дисертацій, отримання звання професора, конкурс на завідування кафедрою, в пам'яті ще свіжі спогади... а вже хилиться друга половина життя.

Роки, роки. Вони біжать невпинно, і чим далі, тим скоріше. Уже настає той час, коли ти, хочеш того, чи ні, а оглядаєшся на пройдений шлях, бачиш, що встиг в житті зробити, а що ще потрібно, що ще попереду. Плануєш, прикидаєш, зіставляєш, а роки біжать і біжать, як та кришталево чиста вода з карпатського потічка.

Тарас Михайлович Ганич народився 11 листопада 1958 року в м. Ужгород у сім'ї лікарів - професорів Оксани та Михайла Ганичів. краї.

Сім’я Ганичів-Мандзюків має глибокі корені в

Дід - Микола Іванович Мандзюк, вчитель, відомий у краї просвітитель, брав безпосередню участь у подіях буремного 1939 року, разом з Президентом Волошином творив Карпатську Україну, будучи членом Сойму, пережив іiі велич і трагедію, залишився до кінця свого життя вірним цим ідеалам.

Бабуся - Ганна Іванівна - була вчителькою української мови. Свідома українка, любила творчість Тараса Шевченка, і в честь нього був названий внук. Малий Тарас ріс і виховувався в сім’і щирих українців, любив рідну мову, літературу, пісню і в 1975 р. після закінчення із золотою медаллю Ужгородської середньої школи № 1 імені Тараса Григоровича Шевченка перед ним постала дилема - куди вступати: на філологічний чи медичний факультет університету.

Зрештою Тарас Михайлович зупинив свій вибір на медичному факультеті Ужгородського університету, який закінчив із відзнакою у 1981 році. За розподілом був направлений на роботу в санаторій «Сонячне Закарпаття», де працював протягом 9 років, спочатку завідувачем відділення, згодом заступником головного лікаря. В подальшому працював у Закарпатському обласному гастроентерологічному диспансері.

У 1988 році захистив кандидатську дисертацію на тему «Скрининг-диагностика хронического панкреатита».
При виконанні теми дисертації Тарасом Михайловичем вперше було розроблено комплекс беззондових скринінг-тестів для діагностики хронічного панкреатиту, простих і доступних у виконанні, необтяжливих для хворого. Разом із тим вони давали достатню інформацію про стан підшлункової залози, були придатні для використання як в умовах поліклініки, так і стаціонару, та в санаторно-курортних установах.

Т. М. Ганич вперше вивчив бактеріальне обсіменіння біоактивних точок організму при хронічному панкреатиті, вираженість якого залежала від клінічного перебігу захворювання.

У 1996 році достроково захистив докторську дисертацію $з$ проблематики обстеження та оздоровлення осіб, які потерпіли внаслідок аварії на Чорнобильській АЕС - «Клініко-фармакологічні аспекти корекції гомеостазу в осіб з радіонуклідним впливом».

Роками вивчаючи стан здоров'я людей, які потерпіли внаслідок аварії на Чорнобильській АЕС, Тарас Михайлович вперше розробив концепцію впливу малих доз радіації на здоров'я людини. Ним запропоновано комплекс заходів для оздоровлення контингентів населення, контамінованого радіонуклідами внаслідок аварії на Чорнобильській AEC: зокрема, з використанням дезінтоксикаційного фіточаю «Карпатський», ентеросорбентів (наприклад, «Фітосорб»), адаптогенів (наприклад, «Ехінофіт») тощо. Необхідно зазначити, що запропонованими препаратами було безоплатно забезпечено населення, яке ще проживало в 30кілометровій зоні.

У подальшому Тарас Михайлович ще неодноразово буде повертатися до Чорнобильської тематики.

У 1998 році він отримує звання доцента, в 2000 році - професора. Родина Ганичів - чи не єдина в Україні, де в сім’ї три професори.

Із 2001 року очолює кафедру факультетської терапії Ужгородського університету.

Iз приходом Тараса Михайловича на кафедру активізувалася методична робота: з'явилися методичні розробки з гастроентерології, пульмонології, видано навчальний посібник $з$ клінічної фітотерапії, затверджений Міністерством освіти і науки України, готуються нові лекції, тести та методичні розробки у відповідності до вимог болонського процесу. 
Популярністю серед студентів та викладачів користуються такі видання, як «Радіація, здоров'я, радіопротекція» (1996), «Твоє здоров’я в твоїх руках» (1998), «Хронічний панкреатит» (2000), «Клінічні класифікації захворювань внутрішніх органів» (2001), «Практична дієтологія» (2004), «Клінічна фітотерапія» (2008) та інші.

Тарас Михайлович є автором (співавтором) понад 300 наукових пращь, в тому числі 8 монографій, патентів на винаходи та низки науковопрактичних $і$ навчально-методичних видань. Під його керівництвом виконано 6 дисертаційних робіт

Тарас Михайлович $є$ заступником голови спеціалізованої вченої ради Ужгородського державного університету та членом спеціалізованої вченої ради у Львівському державному медичному університеті із захисту докторських та кандидатських дисертацій.

Т. М. Ганич - доповідач та учасник численних міжнародних наукових форумів. Налагодив безпосередні наукові контакти і $є$ співкерівником низки наукових тем із вченими Словаччини, Угорщини. Уже 10 років є організатором проведення міжнародної, міждисциплінарної науково-практичної конференції, присвяченої сучасним аспектам збереження здоров'я людини на базі санаторію «Квітка Полонини». Усього за цей період було видано 12 збірників праць учасників конференцій, загальним обсягом 4100 сторінок.
Основні напрями сучасних наукових досліджень Тараса Михайловича - поєднана патологія органів травлення, оздоровлення людей із постчорнобильським синдромом, вплив екзоекологічних факторів на ендоекологію, йододефіцитна патологія, практична фітотерапія.

С керівником медичного студентського наукового товариства і на громадських засадах виконує функцію заступника декана медичного факультету УжНУ 3 наукової роботи. Завдяки його енергії, старанню та організаторським здібностям наукові студентські конференції завжди проходять цікаво, із залученням студентів з інших медичних закладів України та закордону, і що суттєво, систематично випускаються матеріали наукових студентських конференцій. Ряд студентів медичного факультету також виступали на конференціях в інших навчальних закладах України та Європи.

Користується повагою серед студентів, молоді колег та пацієнтів.

Тарас Михайлович - високоосвічена людина: володіє п'ятьма іноземними мовами, що дає йому можливість викладати іноземним студентам, вільно спілкуватися 3 колегами 3 інших країн та достойно представляти університет на різних міжнародних форумах.

Тож із нагоди ювілею бажаємо Вам, Тарасе Михайловичу, міцного здоров'я, нових творчих здобутків, літ до ста рости без старості.

Колектив кафедри факультетської терапії 